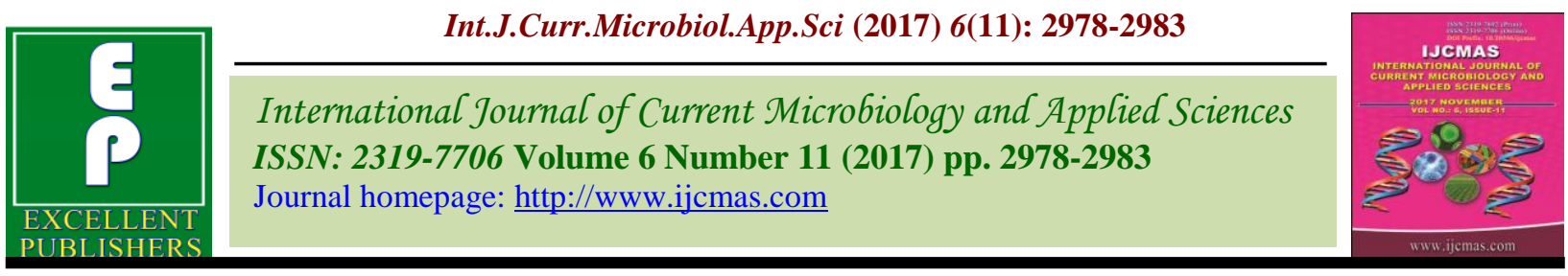

Original Research Article

https://doi.org/10.20546/ijcmas.2017.611.348

\title{
Effect of Different Level of Potassium and Vermicompost on Tuber Quality of Potato (Solanum tuberosum L.) and Storage
}

\author{
Smita Agrawal", R. Lekhi and Payal Patidar \\ RVSKVV Gwalior, India \\ *Corresponding author
}

A B S T R A C T

\begin{tabular}{|l|}
\hline Ke y w o r d s \\
Quality parameters, \\
$\begin{array}{l}\text { Dry matter, Specific } \\
\text { gravity, Physiological } \\
\text { weight loss\% and } \\
\text { rotting \%. }\end{array}$ \\
\hline Article Info \\
\hline $\begin{array}{l}\text { Accepted: } \\
\text { 24 September } 2017 \\
\text { Available Online: } \\
\text { 10 November } 2017\end{array}$ \\
\hline
\end{tabular}

Experiment was conducted in factorial randomized blocked design with three replications comprised of eight treatments of four levels of potassium i.e. $50,100,150$ and $200 \mathrm{~kg} \mathrm{ha}^{-1}$ and two levels of vermicompost i.e. 0 and $20 \mathrm{tha}^{-1}$. Significantly maximum dry matter content, specific gravity, TSS\%, physiological weight loss $\%$ and rotted $\%$ was noted in treatments $\mathrm{K}_{4}\left(200 \mathrm{kgK}_{2} \mathrm{O} / \mathrm{ha}\right)$ followed by $\mathrm{K}_{3}\left(150 \mathrm{kgK}_{2} \mathrm{O} / \mathrm{ha}\right)$ and lowest dry matter content, specific gravity, TSS\%, physiological weight loss \% and rotted \% was recorded in treatment $\mathrm{K}_{1}\left(50 \mathrm{kgK}_{2} \mathrm{O} / \mathrm{ha}\right)$. Treatment $\mathrm{VC}_{1}\left(20 \mathrm{t} \mathrm{VC} \mathrm{ha}{ }^{-1}\right)$ was recorded significantly maximum in all quality and storage parameters, while, it was recorded lowest in treatment $\mathrm{VC}_{0}\left(0 \mathrm{t} \mathrm{VC} \mathrm{ha}^{-1}\right)$. Higher dry matter content $(\%)$ was achieved which might be due to application of vermicompost that played a positive role in affecting dry matter of tubers. Among interaction effects, significantly maximum dry matter content, specific gravity, physiological \% and rotting \% was recorded in treatments $\mathrm{K}_{4} \mathrm{VC}_{1}\left(200 \mathrm{kgK}_{2} \mathrm{O} / \mathrm{ha}+20 \mathrm{t}\right.$ $\mathrm{VC} / \mathrm{ha})$ followed by $\mathrm{K}_{3} \mathrm{VC}_{1}\left(150 \mathrm{kgK}_{2} \mathrm{O} / \mathrm{ha}+20 \mathrm{t} \mathrm{VC} / \mathrm{ha}\right)$ and $\mathrm{K}_{2} \mathrm{VC}_{1}\left(100 \mathrm{kgK}_{2} \mathrm{O} / \mathrm{ha}+20 \mathrm{t}\right.$ $\mathrm{VC} / \mathrm{ha})$. While, the minimum was recorded in the treatment $\mathrm{K}_{1} \mathrm{VC}_{0}(50 \mathrm{~kg} \mathrm{~K} \mathrm{O} / \mathrm{ha}+0 \mathrm{t}$ $\mathrm{VC} / \mathrm{ha}$ ). Higher dry matter content $(\%)$ was achieved which might be due to application of vermicompost and potassium that played a positive role in affecting dry matter of tubers.

\section{Introduction}

The potato (Solanum tuberosum L.) is one of the most important food crops both in developed as well as in developing countries. The widely grown cultivated potato is tetraploid with $2 \mathrm{n}=48$. Potato protein is superior to that of cereals and rich in essential amino acid 'lysine'. To a large portion of our population to whom citrus fruits are out of reach, potato remains a cheap and rich source of vitamin C. Potato produces highest dry matter, carbohydrates, edible protein, minerals and vitamin $\mathrm{C}$ and $\mathrm{B}$ per unit area and time among the major food crops (Kumar et al., 2013; Lokendrajit et al., 2013). It ranks fourth among major food crops of the world with an area of 19.26 million ha, production and productivity of 320.71 million tonnes and 16.64 tonnesha $^{-1}$, respectively (FAO. 2008). In India the area, production and productivity of potato are 2151thousand ha, 48237thousand metric tonnes and 22.42 tonnes $\mathrm{ha}^{-1}$ in (2016-17) (Anonymous 201617). Potassium has a vital role in photosynthesis process that favours high energy status, regulates opening and closing of leaf stomata, nutrients translocation, water uptake, vitamin contents and organic acid concentration in plants (Bergmann, 
1992).Potassium enhances storage life and improves shipping quality of potato as well as extends their shelf life (Martin-Prevel, 1989). Potassium influences synthesis, location, transformation and storage of carbohydrates, tuber quality and processing characteristics as well as plant resistance to stress and diseases (Ebert, 2009).Application of vermicompost increased seed germination, stem height, number of leaves, leaf area, leaf dry weight, root length, root number, total yield, number of fruits plant ${ }^{-1}$, chlorophyll content, TSS of juice, micro and macro nutrients, carbohydrate $(\%)$ and protein $(\%)$ content and improved the quality of the fruits and seeds (Joshi et al., 2014).

\section{Materials and Methods}

The fieldexperiment was laid out in the experimental field of department of Horticulture, College of Agriculture, Rajmata Vijayaraje Scindia Krishi Vishwa Vidyalaya, Gwalior (M.P.) during autumn-winter season during the year 2015 - 16 (first year), 2016 17 (second year) and pooled. Experiment was conducted in factorial randomized blocked design with three replication comprised of eight treatments of four levels of potassium i.e. $50,100,150$ and $200 \mathrm{~kg} \mathrm{ha}^{-1}$ and two levels of vermicompost i.e. 0 and 20 tha $^{-1}$. As per the treatment vermicompost was applied during final land preparations full dose of Phosphorus and Potash applied as basal dose. Half of nitrogen was applied as basal dose and remaining half was applied as top dressing at the time of first earthing up (30 days after planting).

\section{Results and Discussion}

The present investigation has been carried out during winter season (November to April) to find out the effect of Potassium and Vermicompost levels on quality of potato tubers.

\section{Quality character}

\section{Dry matter content (\%)}

The data for various treatments with respect to the dry matter content (\%) showed significantly maximum $(24.73,25.30$ and $25.01 \%$ ) dry matter content was noted in treatments $\mathrm{K}_{4}\left(200 \mathrm{kgK}_{2} \mathrm{O} / \mathrm{ha}\right)$ followed by $\mathrm{K}_{3}$ (150 $\left.\mathrm{kgK}_{2} \mathrm{O} / \mathrm{ha}\right)(24.27,24.84$ and 24.56\%) and lowest (23.71, 23.98 and 23.84\%) dry matter content was recorded in treatment $\mathrm{K}_{1}$ (50 $\mathrm{kgK}_{2} \mathrm{O} / \mathrm{ha}$ ) in first, second year and pooled, respectively. TreatmentVC ${ }_{1}(20 \mathrm{t} \mathrm{VC}$ $\mathrm{ha}^{-1}$ ) was recorded significantly maximum (24.34, 24.88 and $24.61 \%$ ) dry matter content, while, it was recorded lowest $(24.04,24.32$ and $24.18 \%)$ in treatment $\mathrm{VC}_{0}\left(0 \mathrm{t} \mathrm{VC} \mathrm{ha}^{-1}\right)$ in first, second year and pooled, respectively. Interaction effects of various treatments do not exert any significant effect in second year. Significantly maximum 25.01 and $25.35 \%$ dry matter content was recorded in treatments $\mathrm{K}_{4} \mathrm{VC}_{1}\left(200 \mathrm{kgK}_{2} \mathrm{O} / \mathrm{ha}+20 \mathrm{t} \mathrm{VC} / \mathrm{ha}\right)$ followed by $\mathrm{K}_{3} \mathrm{VC}_{1} \quad\left(150 \quad \mathrm{kgK}_{2} \mathrm{O} / \mathrm{ha}+20 \mathrm{t} \mathrm{VC} / \mathrm{ha}\right)$ $(24.28$ and $24.75 \%)$ and $\mathrm{K}_{2} \mathrm{VC}_{1} \quad(100$ $\mathrm{kgK}_{2} \mathrm{O} / \mathrm{ha}+20 \mathrm{t} \mathrm{VC/ha)} \mathrm{(24.05} \mathrm{and} 24.19 \%$ ) in first year and pooled, respectively. While, the minimum 23.41 and $23.53 \%$ was recorded in the treatment $\mathrm{K}_{1} \mathrm{VC}_{0}\left(50 \mathrm{kgK}_{2} \mathrm{O} / \mathrm{ha}+0 \mathrm{t}\right.$ $\mathrm{VC} / \mathrm{ha}$ ) in first year and pooled, respectively. Interaction effects of year and potassium (YXP) and year, potassium and vermicompost (YXPXV) on dry matter content \% were nonsignificant. Higher dry matter content (\%) was achieved which might be due to application of vermicompost that played a positive role in affecting dry matter of tubers. These findings are in agreement with the findings of Das et al., (2004) Mária et al., (2013) and Brijesh Ram et al., (2017).

\section{Specific gravity}

Treatment $\mathrm{K}_{4}\left(200 \mathrm{kgK}_{2} \mathrm{O} / \mathrm{ha}\right.$ ) had the highest specific gravity (1.095, 1.094 and 1.095) 
followed by $\mathrm{K}_{3}\left(150 \mathrm{kgK}_{2} \mathrm{O} / \mathrm{ha}\right)(1.092,1.093$ and 1.093) with non-significant differences, while the minimum value for specific gravity $(1.085,1.086$ and 1.086) was noted in treatment $\mathrm{K}_{1}\left(50 \mathrm{kgK}_{2} \mathrm{O} / \mathrm{ha}\right)$ in first, second year and pooled, respectively. Treatment $\mathrm{VC}_{1}$ $\left(20 \mathrm{t} \mathrm{VC} \mathrm{ha}^{-1}\right)$ was recorded maximum (1.092, 1.094 and 1.093) specific gravity, while, it was recorded lowest 1.089, 1.090 and 1.089in treatment $\mathrm{VC}_{0}\left(0 \mathrm{t} \mathrm{VC} \mathrm{ha}{ }^{-1}\right)$ in first, second year and pooled, respectively. Inconsistent and contradictory results on tuber specific gravity were obtained by different workers due to variety and interaction effect of organic and inorganic fertilizers. The reason could be due to differences in variety used and soil nutrient status and management practices. Findings are in agreement with those of Brijesh Ram et al., (2017).

Interaction effects of potassium and vermicompost (YXP), year and potassium
(YXP), year and vermicompost (YXV) and year, potassium and vermicompost (YXPXV) on specific gravity were non-significant. The specific gravity gradually increases in potato tubers with increase in potassium and vermicompost application. The findings are in close harmony with the result of Fekadu Asfaw (2016).

\section{TSS (\%)}

In treatments $\mathrm{K}_{4}\left(200 \mathrm{kgK}_{2} \mathrm{O} / \mathrm{ha}\right)$ had the significantly highest TSS (5.98, 5.98 and $5.98 \%)$ followed by $\mathrm{K}_{3}\left(150 \mathrm{kgK}_{2} \mathrm{O} / \mathrm{ha}\right)(5.84$, 5.87 and $5.86 \%$ ), while the minimum value for TSS (5.31, 5.38 and 5.35\%) was noted in treatment $\mathrm{K}_{1}\left(50 \mathrm{kgK}_{2} \mathrm{O} / \mathrm{ha}\right)$ in first, second year and pooled, respectively and which were at par with each other in second year. Total soluble solid of tuber increased as the source of $\mathrm{K}$ fertilizer dose increased. Findings are in agreement with those of Pervez et al., (2013).

Table.1 Effect of potassium and vermicompost levels on quality of potato tubers and storage

\begin{tabular}{|c|c|c|c|c|c|c|}
\hline $\begin{array}{l}\text { Treat. } \\
\text { Symb. }\end{array}$ & Treatment & $\begin{array}{c}\text { Dry matter } \\
\text { content }\end{array}$ & $\begin{array}{c}\text { Specific } \\
\text { gravity }\end{array}$ & $\begin{array}{l}\text { TSS } \\
(\%)\end{array}$ & $\begin{array}{c}\text { Physiological } \\
\text { weight loss }(\%)\end{array}$ & $\begin{array}{c}\text { Rotting } \\
(\%)\end{array}$ \\
\hline $\mathrm{K} 1$ & $50 \mathrm{kgK} 2 \mathrm{O} / \mathrm{ha}$ & 23.84 & 1.086 & 5.35 & 7.34 & 0.79 \\
\hline $\mathrm{K} 2$ & $100 \mathrm{kgK} 2 \mathrm{O} / \mathrm{ha}$ & 24.18 & 1.091 & 5.72 & 5.28 & 0.59 \\
\hline $\mathrm{K} 3$ & $150 \mathrm{kgK} 2 \mathrm{O} / \mathrm{ha}$ & 24.56 & 1.093 & 5.86 & 4.55 & 0.46 \\
\hline $\mathrm{K} 4$ & $200 \mathrm{kgK} 2 \mathrm{O} / \mathrm{ha}$ & 25.01 & 1.095 & 5.98 & 3.76 & 0.39 \\
\hline $\mathrm{SEm} \pm$ & & 0.07 & 0.009 & 0.04 & 0.01 & 0.01 \\
\hline CD 5\% & & 0.19 & N.S. & 0.11 & 0.03 & 0.03 \\
\hline $\mathrm{VC} 0$ & $0 \mathrm{t} \mathrm{VC/ha}$ & 24.18 & 1.089 & 5.63 & 5.44 & 0.64 \\
\hline $\mathrm{VC} 1$ & $20 \mathrm{t} \mathrm{VC/ha}$ & 24.61 & 1.093 & 5.82 & 5.02 & 0.48 \\
\hline $\mathrm{SEm} \pm$ & & 0.05 & 0.006 & 0.03 & 0.01 & 0.01 \\
\hline CD 5\% & & 0.13 & N.S. & 0.08 & 0.02 & 0.02 \\
\hline $\mathrm{K} 1 \mathrm{VC} 0$ & $50 \mathrm{kgK} 2 \mathrm{O} / \mathrm{ha}+0 \mathrm{t} \mathrm{VC} / \mathrm{ha}$ & 23.53 & 1.083 & 5.23 & 7.72 & 0.90 \\
\hline $\mathrm{K} 1 \mathrm{VC} 1$ & $50 \mathrm{kgK} 2 \mathrm{O} / \mathrm{ha}+20 \mathrm{t} \mathrm{VC/ha}$ & 24.16 & 1.089 & 5.46 & 6.97 & 0.68 \\
\hline $\mathrm{K} 2 \mathrm{VC} 0$ & $100 \mathrm{kgK} 2 \mathrm{O} / \mathrm{ha}+0 \mathrm{t} \mathrm{VC/ha}$ & 24.17 & 1.090 & 5.61 & 5.47 & 0.62 \\
\hline $\mathrm{K} 2 \mathrm{VC} 1$ & $100 \mathrm{kgK} 2 \mathrm{O} / \mathrm{ha}+20 \mathrm{t} \mathrm{VC} / \mathrm{ha}$ & 24.19 & 1.093 & 5.82 & 5.10 & 0.57 \\
\hline $\mathrm{K} 3 \mathrm{VC} 0$ & $150 \mathrm{kgK} 2 \mathrm{O} / \mathrm{ha}+0 \mathrm{t} \mathrm{VC} / \mathrm{ha}$ & 24.36 & 1.092 & 5.78 & 4.66 & 0.55 \\
\hline $\mathrm{K} 3 \mathrm{VC} 1$ & $150 \mathrm{kgK} 2 \mathrm{O} / \mathrm{ha}+20 \mathrm{t} \mathrm{VC} / \mathrm{ha}$ & 24.75 & 1.094 & 5.94 & 4.43 & 0.37 \\
\hline $\mathrm{K} 4 \mathrm{VC} 0$ & $200 \mathrm{kgK} 2 \mathrm{O} / \mathrm{ha}+0 \mathrm{t} \mathrm{VC/ha}$ & 24.68 & 1.093 & 5.90 & 3.93 & 0.48 \\
\hline $\mathrm{K} 4 \mathrm{VC1}$ & $200 \mathrm{kgK} 2 \mathrm{O} / \mathrm{ha}+20 \mathrm{t} \mathrm{VC} / \mathrm{ha}$ & 25.35 & 1.096 & 6.05 & 3.58 & 0.30 \\
\hline $\mathrm{SEm} \pm$ & & 0.09 & 0.013 & 0.05 & 0.02 & 0.01 \\
\hline $\mathrm{CD} 5 \%$ & & 0.27 & N.S. & N.S. & 0.05 & 0.04 \\
\hline
\end{tabular}


TreatmentVC $1\left(20 \mathrm{t} \mathrm{VC} \mathrm{ha}^{-1}\right)$ was recorded significantly maximum $(5.75, \quad 5.88$ and $5.82 \%)$ TSS, while, it was recorded lowest $5.63,5.63$ and 5.63in treatment $\mathrm{VC}_{0}(0 \mathrm{t} \mathrm{VC}$ $\mathrm{ha}^{-1}$ ) in first, second year and pooled, respectively. The highest T.S.S content in tuber might be due to maximum moisture content, dry weight of tuber because organic fertilizers carry almost all micro and macro nutrients that are required for the plants growth. The findings are in close harmony with the result of Joshi et al., (2014) and Koodi et al., (2017).

Interaction effects of various treatments do not exert any significant effect in first, second year and pooled.

\section{Physiological weight loss (\%)}

The minimum reduction in physiological weight loss $(3.76 \%)$ was observed in treatment $\mathrm{K}_{4}\left(200 \mathrm{kgK}_{2} \mathrm{O} / \mathrm{ha}\right.$ ) followed by $\mathrm{K}_{3}$ $\left(150 \mathrm{kgK}_{2} \mathrm{O} / \mathrm{ha}\right)(4.55 \%)$, while the maximum value of physiological weight loss (7.34\%) was noted in treatment $\mathrm{K}_{1}\left(50 \mathrm{kgK}_{2} \mathrm{O} / \mathrm{ha}\right)$. Jackson and Mc Bride (1986) found that potassium application reduced the incidence of hollow heart and provides resistance against pest and diseases during storage. These findings are in agreement with the findings of Mondal et al., (2007) and Bansal and Trehan (2011).

TreatmentVC $1\left(20 \mathrm{t} \mathrm{VC} \mathrm{ha}^{-1}\right)$ was recorded significantly lowest $(5.02 \%)$ physiological weight loss, while, it was recorded maximum (5.44\%)in treatment $\mathrm{VC}_{0}\left(0 \mathrm{t} \mathrm{VC} \mathrm{ha}^{-1}\right)$. Treatment $\mathrm{K}_{4} \mathrm{VC}_{1}\left(200 \mathrm{kgK}_{2} \mathrm{O} / \mathrm{ha}+20 \mathrm{tVC} / \mathrm{ha}\right)$ was recorded significantly minimum (3.58\%) physiological weight loss followed by $\mathrm{K}_{4} \mathrm{VC}_{0}$ (200 $\mathrm{kgK}_{2} \mathrm{O} / \mathrm{ha}+0 \mathrm{t} \mathrm{VC/ha)} \mathrm{(3.95 \% )} \mathrm{and}$ $\mathrm{K}_{3} \mathrm{VC}_{1}\left(150 \mathrm{kgK}_{2} \mathrm{O} / \mathrm{ha}+20 \mathrm{t} \mathrm{VC/ha}\right)(4.43 \%)$ as compared to other treatments. While, it was noted maximum $(7.72 \%)$ in treatment $\mathrm{K}_{1} \mathrm{VC}_{0}$ (50 $\mathrm{kgK}_{2} \mathrm{O} / \mathrm{ha}+0 \mathrm{t} \mathrm{VC/ha)}$. This might be due to inorganic fertilization promotes big sized tubers which may contain more water content than the organic fertilized tubers. The rate at which water will evaporate from a tuber in response to the above tendency is directly proportional to the difference between the equilibrium water vapour pressure of the tuber and the water vapour pressure of the air in contact with it. Such gradients are common in stores not equipped with forced air ventilation. It has been also observed that when potatoes were stored at ambient temperatures there was excessive sprouting and weight loss. The findings are in close harmony with the result of Kanbi and Bhatnagar (2005) and Prasad (2010).

\section{Rotting (\%)}

The minimum reduction in rotting $(0.39 \%)$ was observed in treatment $\mathrm{K}_{4}\left(200 \mathrm{kgK}_{2} \mathrm{O} / \mathrm{ha}\right)$ followed by $\mathrm{K}_{3}\left(150 \mathrm{kgK}_{2} \mathrm{O} / \mathrm{ha}\right)(0.46 \%)$, while the maximum value of rotting $(0.79 \%)$ was noted in treatment $\mathrm{K}_{1}\left(50 \mathrm{kgK}_{2} \mathrm{O} / \mathrm{ha}\right)$. TreatmentVC ${ }_{1}\left(20 \mathrm{t} \mathrm{VC} \mathrm{ha}^{-1}\right)$ was recorded significantly lowest $(0.48 \%)$ rotting, while, it was recorded maximum $(0.64 \%)$ in treatment $\mathrm{VC}_{0}\left(0 \mathrm{t} \mathrm{VC} \mathrm{ha}{ }^{-1}\right)$. It may be due to more water content inside the tuber, which mainly caused by the following process; respiration, sprouting, evaporation of water from the tubers, spread of diseases, change in the chemical composition and physical properties of tubers and damage by extreme temperature and relative humidity. Findings are in agreement with those of Bansal and Trehan (2011) and Hosseini et al., (2017).Treatment $\mathrm{K}_{4} \mathrm{VC}_{1}\left(200 \mathrm{kgK}_{2} \mathrm{O} / \mathrm{ha}+20 \mathrm{t} \mathrm{VC} / \mathrm{ha}\right)$ was recorded significantly minimum $(0.30 \%)$ rotting followed by $\mathrm{K}_{3} \mathrm{VC}_{1}\left(150 \mathrm{kgK}_{2} \mathrm{O} / \mathrm{ha}+\right.$ $20 \mathrm{t} \mathrm{VC/ha)}(0.37 \%)$ as compared to other treatments. While, it was noted maximum $(0.90 \%)$ in treatment $\mathrm{K}_{1} \mathrm{VC}_{0}\left(50 \mathrm{kgK}_{2} \mathrm{O} / \mathrm{ha}+\right.$ $0 \mathrm{t} \mathrm{VC/ha)}$. The findings are in close harmony with the result of Kanbi and Bhatnagar (2005) and Prasad (2010). 
Over all it was seen that potassium rate of 200 $\mathrm{kg} / \mathrm{ha}$ increased the quality parameters in all evaluated trials. It also appears that vermicompost showed positive relationship with quality attributes. Regarding to combined application of potassium and vermicompost it can be set that potassium $(200 \mathrm{~kg} / \mathrm{ha})+$ vermicompost $(20 \mathrm{t} / \mathrm{ha})$ is favorable for enhancing quality tubers.

\section{References}

Anonymous (2016-17). Third advance estimates for the year 2016-17 of area and production of horticulture crops. National Horticulture Board. Govt. of India, Gurgaon, India. http://www.nhb.gov.in. pp 2.

Bansal, S.K. and Trehan, S.P. (2011). Effect of potassium on yield and processing quality attributes of potato. Karnataka Journal of. Agricultural. Science. 24 (1): 48-54.

Brijesh, Ram; Singh, B.N. and Hitesh Kumar (2017). Impact of various organic treatments on growth, yield and quality parameters of potato. Int. J. Pure Applied Bioscience. 5 (3):643-647.

Das, P., Barik, A.K., Chattopadhyay, G.N. and Mandal, P. (2004). Effect of integrated nitrogen management through vermicompost and urea on growth and productivity of potato in red and lateritic soil. Indian Agriculturist. 48 (3/4): 171-174.

Ebert, G. (2009). Potassium nutrition and its effect on quality and post-harvest properties of potato. Proceedings of the International Symposium onPotassium Role and Benefits in Improving Nutrient Management for Food Production, Quality and Reduced Environmental Damages. 1: 637- 638.

FAO, (2008). Highlighting the role of potato in fighting against hunger and poverty. FAO, Rome, Italy.
Fekadu Asfaw (2016). Effect of integrated soil amendment practices on growth and seed tuber yield of potato (Solanum tuberosum L.) at Jimma Arjo, Western Ethiopia. Journal of Natural Sciences Research. 6 (15): 38-63.

Hosseini, Aazadeh; Nemati, Seyed Hossein; Mohamad Khajehosseini and Hossein Aroiee (2017). Effects of different nitrogen and solupotasse fertilizer rate on yield and yield components of Potato. IIOAB Journal. 8 (1): 92-97.

Joshi, Rakesh; Singh, Jaswinder and Vig, Adarsh Pal (2014). Vermicompost as an effective organic fertilizer and biocontrol agent: effect on growth, yield and quality of plants. Reviews in Environmental Science and Biotechnology. pp 1-25.

Kanbi, V.H. and Bhatnagar, R. (2005). Effect of organic and inorganic fertilizers on yield, chlorophyll content, dry matter and keeping quality of potato. Potato J.32 (3-4): 161-162.

Koodi, Sunita; Singh, S.P; Rolaniya, Manoj Kumar; Gathala, Suman and Choudhary, Rajbala (2017). Effect of NPK, FYM and vermicompost on growth, yield and quality of sweet potato (Ipomoea batatas Lam.). Chemical Science Review and Letters. 6 (21): 495-499.

Kumar, M., Baishaya, L.K., Ghosh, D.C., Gupta, V.K. and Verma, M.R. (2013). Effects of organic manures, chemical fertilizers and biofertilizers on growth and productivity of rainfed potato in the eastern Himalayas. Journal of Plant Nutrition, 36:1065-1082.

Lokendrajit, N., Singh, C.B., Swapana, N. and Singh, M.S. (2013). Evaluation of nutritional value of two local potato cultivars (Aberchaibi and Amubi) of Manipur, Northeast India. Bioscan 8: 589-593.

Mária, K., Peter, K. and Marek, R. (2013). 
The effect of different doses application of dry granulated vermicompost on yield parameters of maize and potatoes. Res. Gate. $1: 8$ - 14.

Martin-Prevel, P.J. (1989). Physiological processes related to handling and storage quality of crops. In: Proceedings of the $21^{\text {st }}$ IPI Colloquium on: Methods of $\mathrm{K}$ Research in Plants, held at Louvain-la-Neuve, Belgium, 19-21 June 1989. International Potash Institute, Bern, Switzerland. pp. 219-248.

Mondal, S.S., Saha, Mithun; Acharya, D., Patra D. and Chatterjee, S. (2007). Integrated effect of nitrogen and potassium with or without sulphur and farm yard manure on potato tuber yield, storage quality and soil fertility status.Potato J. 34 (1-2): 97-98.

Pervez, Muhammad Aslam; Choudhary Muhammad Ayyub; Muhammad Rashid Shaheen and Munawar Ahamd Noor (2013). Determination of physio morphological characteristics of potato crop regulated by potassium management. Pak. Journal of Agriculture Science. 50 (4): 611-615.

Prasad, K.K. (2010). Effect of different organic source on growth, yield and quality of potato (Solanum tuberosum) varieties. Abstract of PhD thesis, Rajendra Agricultural University, Bihar, Pusa (Samastipur), India. pp: 2.

\section{How to cite this article:}

Smita Agrawal, R. Lekhi and Payal Patidar. 2017. Effect of Different Level of Potassium and Vermicompost on Tuber Quality of Potato (Solanum tuberosum L.) and Storage. Int.J.Curr.Microbiol.App.Sci. 6(11): 2978-2983. doi: https://doi.org/10.20546/ijcmas.2017.611.348 